Article

\title{
Energy Management in the Operation of Enterprises in the Light of the Applicable Provisions of the Energy Efficiency Directive (2012/27/EU)
}

\author{
Katarzyna Grondys $1, * \mathbb{C}$, Armenia Androniceanu ${ }^{2,3}$ a and Zdzisława Dacko-Pikiewicz ${ }^{4}(\mathbb{C}$ \\ 1 The Management Faculty, Czestochowa University of Technology, Armii Krajowej 19B, \\ 42-201 Czestochowa, Poland \\ 2 Administration and Public Management Faculty, Bucharest University of Economic Studies, 6 Piata Romana, \\ 010374 Bucharest, Romania; armenia.androniceanu@man.ase.ro \\ 3 Research Department, University of Social Sciences, 9 Sienkiewicza St., 90-113 Lodz, Poland \\ 4 The Faculty of Applied Sciences, WSB University, Cieplaka 1c, 41-300 Dabrowa Gornicza, Poland; \\ zdacko@wsb.edu.pl \\ * Correspondence: katarzyna.grondys@wz.pcz.pl; Tel.: +48-34-3250-395
}

Received: 24 July 2020; Accepted: 16 August 2020; Published: 21 August 2020

\begin{abstract}
One of the ways to sustain development is striving for energy efficiency. This is the purpose of directive 2012/27/EU on energy efficiency, which aims at explaining and promoting energy-saving and ecological solutions that allow increasing the output of consumed energy. Several years after implementation, it is possible to assess the directive's usefulness and completeness in a few areas of the economy, in particular in the operation of enterprises, which substantially contribute to the global energy consumption. Therefore, the purpose of the study was defined as an assessment of the execution of the concept of energy efficiency in business operations in EU countries, in accordance with the assumptions of directive 2012/27/EU. The collected raw data were derived from surveys gathered in the process of public consultations of the European Commission regard directive 2012/27/EU on energy efficiency. Resulting observations were analysed using the basic methods of descriptive statistics, along with a factor analysis. A logistic regression model was applied to identify the dependencies between the provisions of the directive and the motivation of enterprises to manage energy. As a result of conducted analyses, conclusions were drawn up concerning the assessment of the content of the directive in regard to activities undertaken by EU enterprises to the favour of effective energy management. Obtained results suggest that there is a need to introduce changes in the provisions of the directive, preceded by consultations with the EU business environment. The analysed literature concerning this issue demonstrates that the effectiveness of energy management is taken into consideration from this angle for the first time in our studies.
\end{abstract}

Keywords: energy management; energy efficiency; enterprise management

\section{Introduction}

The visible influence of economic growth on environmental protection resulted in the related energy effectiveness being perceived as a problem for many countries, which are dependent on fossil fuel [1]. Adverse climatic events and ending nonrenewable energy sources force to seek more efficient manners of using energy. A lack of appropriate mechanisms of delivering, monitoring and controlling energy aggravates existing economic, environmental and social problems [2].

A weak energy policy as well as an inefficient energy network result in an environmental imbalance, even in case of using renewable energy sources [3]. The Directive 2012/27/EU prepared for this purpose is not fully effective, as evidenced by the failure to achieve the energy efficiency set by numerous EU 
Member States. Therefore, the implementation of energy effectiveness constitutes a serious challenge due to the complexity and number of recipients, from the perspective of not only national, regional and local authorities but also households and the industry.

The industrial sector, including production of goods and services, requires a special concentration of such operations due to high energy consumption [4]. Harmful operations of the business sector include high level of generated waste, high greenhouse gas emissions, excessive use of natural energy resources and excessive use of water.

The study may constitute the basis for further exploration of activities implemented in enterprises to optimize the use of energy and reduce the negative effect of their operations on the environment. Studies discussed in this article are to demonstrate whether legal measures provided for in directive 2012/27/EU on energy efficiency, in regard to ensuring the required energy efficiency, constitute a sufficient tool to persuade entrepreneurs to manage energy in their business operations. For this purpose, a set of primary data from directive consultations in EU countries was analysed. This document is composed as follows. First part presents theoretical considerations on environmental and legal conditions of energy efficiency (Literature review). Second shows own studies on the assessment of the directive among EU enterprises (Research section). The last part includes conclusions and recommendations in the area of effective energy management in the entities of European Union (Conclusions).

An analysis of the literature indicated a research gap concerning the approach to energy management by EU enterprises. The current results do not consider the energy management issue in enterprises with regard to compliance with the Directive. The latest research conducted in this area usually focuses on assessing the implementation of the Directive's provisions in EU Member States. For example, Zangheri et al. has made an analysis based on the energy consumption reports of the EU Member States and thus assessed whether they have implemented the required level of energy savings within a period of a few years [5]. In turn, Rosenow and Bayer evaluated the benefits and costs resulting from the implementation of Energy Efficiency Obligations-EEOs in selected EU Member States [6]. Nabitz and Hirzel studied the impact of energy audits on energy management only in large enterprises based on data collected from various public and advisory institutions of the Member States [7].

Our empirical studies fulfilled this gap, thanks to an assessment of the perception of the EU directive on energy effectiveness by business entities. An analysis of this issue is important because EC members strive for sustainable growth by way of, amongst others, reducing the consumption of energy from nonrenewable sources and related emissions, which adversely affect the natural environment. Enterprise, in particular industrial companies, form a group, which is one of the key consumers of energy, thus contributing to substantial participation in the degradation of the environment. All this proves the complexity of the discussed issue and urged researchers to define the following research goal:

Assessment of the approach of enterprises to meet the requirements of directive 2012/27/EU on energy efficiency.

The presented research goal is to verify the following exploratory hypotheses:

Hypothesis 1 (H1). EU enterprises do not understand the content of directive 2012/27/EU on energy efficiency;

Hypothesis 2 (H2). Enterprises do not observe the rules of directive 2012/27/EU on energy efficiency in their operations;

Hypothesis 3 (H3). The lack of understanding of directive 2012/27/EU results in a reluctance to manage energy in EU enterprises. 


\section{Literature Review}

\subsection{Energy Efficiency in Companies}

According to Hsueh and Yan [8], economic and sustainable growth is possible through applying energy systems that eliminate using coal as a source of energy are based on energy-saving solutions, and operate on the basis of an innovative infrastructure of energy networks. According to Eichhammer et al. [9], the main reasons of incorrect energy use concern the industry area. However, the energy demand in this sector substantially restrict the possibilities to apply an energy-saving system due to the differences in the functioning on international markets. Energy use indicators are extremely important also in the context of the given country's attempts to strive for sustainable development. It is important for the interested parties to engage in achieving energy efficiency and generate savings through applying energy management systems based on law regulations and supervision over energy operations [10].

The engagement of public institutions allows satisfying the needs of industrial enterprises in a sustainable manner; thus, reducing the consequences of inaccurate estimations of energy use in the industry. This generates the requirement to make decisions at the national level in regard to defining solutions on the manner of uptake and settlement of used energy in the context of the country's economic development. Solutions aiming at increasing energy efficiency are applied in each sector of the economy. A properly structured energy management system at the country level may constitute an effective solution for problems related with excessive energy consumption. To prevent climate changes, Olsen and Fenhann [11] recommend the application of innovative solutions resulting in a minimization of carbon dioxide emissions to the acceptable level at very low cost. The use of electric devices, which minimize the amount of used energy not only decreases related financial costs but also mostly reduces the uptake of energy, which results in a reduction of the level of gas emissions. Dahmus [12] examined the relation between energy, productivity and use of resources in multiple sectors of the economy, where electric energy is generated from coal, crude oil and natural gas. The results demonstrate that resources used in the long-term and the related energy output do not lead to a general decrease of these resources, as opposed to the short-term perspective when the growth of the output of energy use has exceeded, or was equivalent to, the consumption of resources. Therefore, the price policy and the system of penalties play an important role in energy saving. This is confirmed by observations conducted by Galvin [13], according to whom political interventions constitute the key factors that reduce the rebound effect, which depends on environmental awareness, changes in fuel prices, the level of income or lifestyle. The need to promote energy awareness is confirmed by Vassileva and Campillo [14], according to whom such activities should include both environmental and economic information. Their studies demonstrate that information concerning the use of energy may effectively stimulate proenvironment behaviours of entrepreneurs as well-in some cases by $15-25 \%[15,16]$. The improvement of energy efficiency in the industry sector is deemed to be one of the most important issues with visible influence on the environment.

\subsection{Directive on Energy Efficiency}

An important role in striving for energy efficiency is played by EU ordinances and regulations, which force an adjustment to proenvironmental guidelines. To reduce the greenhouse gas emissions, most European countries intensified their activities on energy efficiency within the scope of their own climate policy $[15,16]$. In the process of striving for the desired energy efficiency, one of the conditions is decarbonization of the EU energy system and a reduction of greenhouse gases even by $95 \%$ by the year 2050-as reflected in the 2020 and 2030 EU energy efficiency goals [17].

The "Europe 2020" strategy, drawn up in 2009, derives from the European Union climate and energy policy and assumed achieving an increase in energy efficiency of $20 \%$ by the year 2020. In turn, the latest arrangements assume increasing energy efficiency by at least $32.5 \%$ by the year 2030 [18]. 
The European Union defined the above goals in regard to striving for energy efficiency through drawing up relevant regulations, laws and activities to promote effective energy management based on directive 2012/27/EU, pursuant to which all EU countries are obliged to use energy most efficiently-from production to the use of final energy [19]. What is more, effective use of resources is to be combined with technological, social and economic conditionings of every country.

The purpose of the directive was, amongst others, to limit the use of energy. An improvement in the efficiency of energy use can help reduce the demand for energy, which leads to reducing contamination, decreases the demand for the essential energy infrastructure, ensures energy sovereignty and reduces energy expenses, which translates to the value of the market of products and services. Directive 2012/27/EU on energy efficiency forces undertaking activities such as [20]:

- Improvement of the efficiency of equipment in the industry sector, and undertaking action towards energy recovery during the production process;

- Insulation of buildings and application of modern heating systems;

- Technological enhancements of energy-intensive equipment and devices;

- Recycling and optimum use of available production resources;

- Development of solutions in the transport sector.

Key benefits of striving towards energy efficiency include [21]:

1. Reducing the costs of energy for the industry sector, which increases the competitiveness of market participants;

2. Lower costs of energy consumption for households, which decreases energy poverty;

3. Own internal energy sources may become sufficient;

4. Reduction of emissions of greenhouse gases and contamination from conventional energy sources.

In spite of the potential benefits of implementing the directive, member states have not yet defined sufficiently ambitious national goals in the scope of energy efficiency to achieve the planned level of savings [22]. At the same time, due to the high level of complexity of the concept of directive implementation, there is no clear definition of energy efficiency or a coherent manner of calculating the use of energy in all countries according to the same criteria, and multiple countries have not reached the defined 2020 energy efficiency [23]. These countries include: Belgium, Bulgaria, Croatia, Cyprus, the Czech Republic, Denmark, Estonia, France, Latvia, Luxembourg, Lithuania, Poland, Portugal and Italy [24]. These countries were requested to properly implement the provisions of the directive on energy efficiency. The procedure also applies to entities conducting business activity in these countries. Environmental problems reported as a result of environmental pollution require the governments to seek new manners, technologies, policies and procedures, which may be implemented to control the pollution and related problems [25].

Observations demonstrate that striving for energy efficiency does not constitute a voluntary choice of each country but an obligation. Joint activities to the benefit of increasing energy efficiency bring numerous advantages, however, achieving these advantages requires fulfilling numerous requirements, starting from changes in the infrastructure through to changes in the awareness. An increase of energy efficiency requires identifying the reasons for the current failure to adjust to the applicable energy laws, in particular in the area of business activity, which is based mainly on using energy resources.

\section{Research Section}

\subsection{Materials and Methods}

The purpose of the research was to assess the execution of the energy efficiency concept in the operations of enterprises in EU countries, pursuant to directive 2012/27/EU. The collected raw data were derived during the European Commission consultations regarding directive 2012/27/EU on energy efficiency and had the form of a survey questionnaire [26]. The main survey questionnaire had 22 
questions. The data are public and are stored in an excel file. They present individual responses provided by 311 representatives of various sectors of the national economy. For the purpose of this research, rows with responses of EU entrepreneurs were left to be further analysed. Then, the text was coded into a numeric system and processed by special statistical software. Finally, the sample included 172 entities, which conduct business activity in the European Union, which constituted $55 \%$ of the initial sample. Other nonbusiness entities are not included in the study and include households, public institutions, public utility entities, NGOs and other. The individual share of the enterprises participating in the survey, depending on a company's seat, is as follows: Austria-5\%, Belgia-10\%, Croatia-2\%, Czech Republic - 5\%, Denmark-6\%, Finland-3\%, France-6\%, Germany-7\%, Hungary-6\%, Ireland-5\%, Italy-6\%, Latvia-3\%, Netherlands- $5 \%$, Poland-3\%, Slovakia-3\%, Spain-4\%, Sweden-6\%, United Kingdom- $5 \%$ and other-9\%.

Due to the nature of the discussed problem, only five questions were selected for the analysis as variables. The following dependent variable was selected:

1. Energy management in EU enterprises in an effective manner, in accordance with the guidelines of directive 2012/27/EU on energy efficiency (Var1).

Explanatory variables include:

1. Clear guidelines referring to the implementation of energy-saving products and services in the given country (Var2);

2. Visibility of information campaigns or other public initiatives concerning increased awareness on energy-saving products and services (Var3);

3. Clarity of regulations on energy readings and settlements (Var4);

4. Clarity of the definition of energy-saving products and services (Var5);

5. Assessment of the potential benefits of the applicable energy efficiency system (Var6).

The hypotheses were verified using selected statistical methods. First, to verify H1 and H2 hypotheses, basic measures of descriptive statistics were used. They are sufficient to estimate the basic characteristics of the examined set. These measures indicate the value that best characterizes all received values [27]. What is more, according to Kowal, these measures, if properly selected, will effectively describe the results of the quality research expressed on the measuring scale [28], i.e., identical as presented in this research. At this stage, mainly the tabular presentation of results was used. The last hypothesis (H3) was verified using a logistic regression model, which allowed assessing the willingness to exercise activities benefiting energy efficiency, as a result of a better understanding of the provisions of the directive. This model is generally applied for binomial variables, the behaviour of which may be predicted based on the dependent variable [29]. The results from the model are clear and easy to interpret; in case of quality data included in the research, this is a particularly important advantage of this method [30]. Besides, "the use of logistic regression is supported by the fact that it is not required to meet many assumptions that are formulated in relation to linear regression and general linear models" [31] (p. 40). For the purpose of analysis, the variables were coded within a binomial system, where 0 means a negative indication and 1 means a positive indication.

To better adjust the variables to the model, and to reduce the scope of the one variable, i.e., benefits from energy management in business activity, building of the model was preceded by a factor analysis. Due to the number of similar categories for Var6, this variable was reduced to several dimensions. The factor analysis method allowed to reduce the number of variables in the researched area, and leave only those variables that actually determine the described phenomenon [32,33].

\subsection{Results}

\subsubsection{Percentage Frequency Distribution of Responses}

Below are presented opinions of companies on the conditions of executing energy efficiency based on directive 2012/27/EU on energy efficiency. Tables 1-3 contain the percentage structure of answers to 
selected questions from the questionnaire, which take into account only "yes" or "no" choices. The tables do not include the answer "neither agree nor disagree".

Table 1. Level of implementation of the energy efficiency concept in EU enterprises.

\begin{tabular}{lcc}
\hline \multicolumn{1}{c}{ Conditions of Implementing the Energy Efficiency Concept } & Yes [\%] & No [\%] \\
\hline Executing the energy efficiency concept in the organization & 68 & 32 \\
\hline $\begin{array}{l}\text { Clarity of guidelines on the implementation of energy-saving products, services } \\
\text { and construction in the given country }\end{array}$ & 19 & 18 \\
\hline $\begin{array}{l}\text { Availability of information campaigns or other public initiatives on energy-saving } \\
\text { products, services and construction }\end{array}$ & 14 & 41 \\
\hline Clear laws on energy measurements and settlements & 31 & 16 \\
\hline Clear definition of energy-saving products, services and construction & 11 & 29 \\
\hline
\end{tabular}

Table 2. Challenges and barriers of implementing energy efficiency in entities.

\begin{tabular}{lcc}
\hline Challenges and Barriers in Implementing Energy Efficiency & Number of “Yes" & Percentage of “Yes" \\
\hline $\begin{array}{l}\text { Selection of a proper set of measures to achieve annual energy } \\
\text { savings of } 1.5 \%\end{array}$ & 35 & $30 \%$ \\
\hline $\begin{array}{l}\text { Too large flexibility in applying a wide scope of energy } \\
\text { efficiency measures }\end{array}$ & 13 & $11 \%$ \\
\hline $\begin{array}{l}\text { Strong objection of energy suppliers and distributors towards } \\
\text { the system, which obliges to strive for energy efficiency }\end{array}$ & 12 & $10 \%$ \\
\hline A lack of effective enforcement of laws & 12 & $10 \%$ \\
\hline A lack of sufficient knowledge and skills & 13 & $11 \%$ \\
\hline $\begin{array}{l}\text { A lack of awareness on systems obliging to strive for } \\
\text { energy efficiency }\end{array}$ & 11 & $9 \%$ \\
\hline $\begin{array}{l}\text { Preparation of a methodology of energy consumption } \\
\text { calculations }\end{array}$ & 5 & $4 \%$ \\
\hline $\begin{array}{l}\text { Ensuring solid and independent monitoring and verification } \\
\text { of energy savings }\end{array}$ & 4 & $3 \%$ \\
\hline $\begin{array}{l}\text { Avoidance of double counting } \\
\text { High administrative charges }\end{array}$ & 1 & $1 \%$ \\
\hline $\begin{array}{l}\text { Ensuring a coherent application of requirements along with } \\
\text { other laws on energy efficiency }\end{array}$ & 1 & $8 \%$ \\
\hline $\begin{array}{l}\text { Limited time frame (2014-2020), which hinders attracting } \\
\text { long-term investments }\end{array}$ & $1 \%$ \\
\hline
\end{tabular}

According to the analysis, one-third of surveyed enterprises does not deal with energy efficiency. The opinion on the existence of sufficient guidelines on energy-saving products, services and construction varies to a large extent. A comparable group of surveyed entities thinks that the guidelines are sufficient (18\%) or not sufficient (19\%). According to almost a half of entities, they did not see any information campaigns or other public initiatives on energy-saving products, services and construction in their country of business. Every third firm entity thinks that the provisions of the directive regarding measurements and settlements are sufficient. A similar number of responses confirms a lack of sufficient guidelines and definitions describing energy-saving products, services and construction. 
Table 3. Mean score of the potential effects of implementing the energy efficiency concept.

\begin{tabular}{lcc}
\hline \multicolumn{1}{c}{ Potential Effects } & Mean & Standard Deviation \\
\hline Lower energy bills for consumers (Var6a) & 3.06 & 1.43 \\
\hline $\begin{array}{l}\text { Increased awareness of consumers in the area of the potential of energy } \\
\text { efficiency (Var6b) }\end{array}$ & 3.64 & 1.05 \\
\hline $\begin{array}{l}\text { Better relations between energy providers, distributors, and clients (Var6c) } \\
\text { Lower costs of producing and supplying energy for the media (Var6d) }\end{array}$ & 2.82 & 1.17 \\
\hline $\begin{array}{l}\text { Better business and administrative environment for the future innovative } \\
\text { energy services (Var6e) }\end{array}$ & 3.54 & 1.05 \\
\hline $\begin{array}{l}\text { Aggregation of small investments (combining into packages/packaging) } \\
\text { (Var6f) }\end{array}$ & 3.26 & 1.16 \\
\hline $\begin{array}{l}\text { Preparation of new financing models, e.g., contracting the energy } \\
\text { characteristics (Var6g) }\end{array}$ & 3.42 & 0.92 \\
\hline Stimulation of energy-efficient renovation of buildings (Var6h) & 3.45 & 1.17 \\
\hline Increased competitiveness on energy markets (Var6i) & 2.56 & 1.17 \\
\hline
\end{tabular}

Table 2 presents the barriers and challenges of effective implementation of the energy efficiency concept that are most often selected by companies. The main challenge is selecting and implementation a proper set of measures to achieve annual energy savings of 1.5\% (Table 2). It is difficult for respondents to define what tools and measures would be appropriate for them to effectively manage energy. Another significant problem is the large flexibility in applying a wide scope of energy efficiency measures and a lack of sufficient knowledge and skills.

Respondents were also asked to assess the potential benefits of implementing the energy efficiency concept; this included nine potential effects for both the entities itself and its environment. Individual positive effects were assessed by respondents on a scale of 1 to 5 , where 1 means-strongly disagree and 5 means-I strongly agree. Table 3 presents these effects along with a mean score and the standard deviation.

It is observed that most potential effects were assessed at the level of 3 on the average and some at 2.5. This proves the high level of scepticism of the surveyed entities towards the proposed energy efficiency regulations. The increased awareness of consumers in the area of the potential of energy efficiency was assessed highest, and the increased competitiveness on energy markets-lowest.

Initial results demonstrate that that not all enterprises implement the energy efficiency concept in their organization. For most of the surveyed businesses, clarity and transparency of related regulations was assessed as low. They are also sceptical towards the possible benefits of observing the energy effectiveness directive. It is assumed that these factors may affect the approach to energy management in surveyed entities. This allows to positively verify hypotheses $\mathrm{H} 1$ and $\mathrm{H} 2$.

\subsubsection{Factor Analysis}

The next stage of studies was to identify the influence of the provisions of the directive on effective energy management in EU enterprises, using the logistic regression model. One of the selected explanatory variables is the group of potential benefits of energy management. To identify the key factors related with the potential benefits of executing the assumptions of the energy directive, an exploratory factor analysis was selected; its advantage is a possibility to set an optimum number of hidden variables, which will sufficiently explain the relations between numerous observable variables. The factor analysis was applied to transform the set of benefits, which may be correlated, into a new uncorrelated set, comparable with the input structure.

For this purpose, first, the assumption of the relationship between the dimensions of the tested variable, defined in Table 3, has been checked. The first step was to examine the correlation between the initial nonparametric variables using a chi square test, which demonstrated that they are all 
significantly correlated for $p<0.05$ (Table 4). In addition, the assumption that none of the deviations for these variables equals zero has been met (Table 3 ).

Table 4. Coefficients of the correlation for the variable "Energy management benefits" (Var6).

\begin{tabular}{cccccccccc}
\hline & Var6a & Var6b & Var6c & Var6d & Var6e & Var6f & Var6g & Var6h & Var6i \\
\hline Var6a & $\mathbf{1 . 0 0}$ & 0.55 & 0.55 & 0.51 & 0.47 & 0.39 & 0.40 & 0.53 & 0.50 \\
\hline Var6b & 0.55 & $\mathbf{1 . 0 0}$ & 0.41 & 0.34 & 0.50 & 0.24 & 0.21 & 0.38 & 0.39 \\
\hline Var6c & 0.55 & 0.41 & $\mathbf{1 . 0 0}$ & 0.44 & 0.35 & 0.26 & 0.29 & 0.24 & 0.56 \\
\hline Var6d & 0.51 & 0.34 & 0.44 & $\mathbf{1 . 0 0}$ & 0.50 & 0.33 & 0.28 & 0.39 & 0.42 \\
\hline Var6e & 0.47 & 0.50 & 0.35 & 0.50 & $\mathbf{1 . 0 0}$ & 0.39 & 0.45 & 0.49 & 0.47 \\
\hline Var6f & 0.39 & 0.24 & 0.26 & 0.33 & 0.39 & $\mathbf{1 . 0 0}$ & 0.43 & 0.32 & 0.35 \\
\hline Var6g & 0.40 & 0.21 & 0.29 & 0.28 & 0.45 & 0.43 & $\mathbf{1 . 0 0}$ & 0.51 & 0.36 \\
\hline Var6h & 0.53 & 0.38 & 0.24 & 0.39 & 0.49 & 0.32 & 0.51 & $\mathbf{1 . 0 0}$ & 0.39 \\
\hline Var6i & 0.50 & 0.39 & 0.56 & 0.42 & 0.47 & 0.35 & 0.36 & 0.39 & $\mathbf{1 . 0 0}$ \\
\hline
\end{tabular}

To confirm the significance of obtained results, researchers also defined the determinant of the correlations matrix and the KMO statistics (Kaiser-Meyer-Olkin Measure of Sampling Adequacy). The value of the determinant of 0.033 is close to zero. A low value of the determinant of the correlation matrix demonstrates numerous significant correlations occurring between the considered variables, which allows continuing the factor analysis process.

Simultaneously, the level of adequacy of the sample in regard to the assumptions of the factor analysis, measured using the KMO statistics for the adequacy of sample selection $=0.86$, may be assessed as very good. The obtained results allowed confirming the good adequacy of data in comparison with the assumptions of the factor analysis. The data, checked for completeness, were subject to an analysis of the main components.

The main goal of the factor analysis is to determine such loading factors so as to allow for a maximum elimination of the influence of initial factors on the main factors. At this, the total variance of individual variables should be assessed as [34]:

- So-called common variability resource, explained by the main factors according to the following formula:

$$
h_{j}^{2}=\sum_{l=1}^{k} w_{j l}^{2}
$$

- So-called specificity, according to the following formula:

$$
w_{j}^{2}=1-h_{j}^{2}
$$

The next stage is a selection of a factor model, which determines the manner of identification of the relevant number of factors to be included in further stages of the underlying study. Strongly corelated variables were determined on the basis of the Kaiser's criterion (Table 5), which allows selecting the factors that explain the variability of at least one initial variable. In effect, two factors were obtained, i.e., bundles of strongly correlated variables. These factors explain in total $60 \%$ of the variances of all initial variables. 
Table 5. Total complete variance within the model.

\begin{tabular}{ccccc}
\hline Value & Own Value & \% of Total Variance & Accumulated Own Value & Accumulated $\%$ \\
\hline 1 & 4.31 & 47.86 & 4.31 & 47.86 \\
\hline 2 & 1.02 & 11.37 & 5.33 & 59.24 \\
\hline
\end{tabular}

To improve and maximize the matching of factors, the factor load matrix was subjected to a Varimax rotation, which allowed to simplify the interpretation of factors through minimizing the number of variables required to explain the given factor. The layout of variables, which form the set dimensions, is presented in Table 6.

Table 6. Factor loads after the Varimax rotation, normalized with the isolation method.

\begin{tabular}{ccc}
\hline Variables & Factor 1 (F1) & Factor 2 (F2) \\
\hline Var6a & 0.715 & 0.403 \\
\hline Var6b & 0.710 & 0.175 \\
\hline Var6c & 0.819 & 0.061 \\
\hline Var6d & 0.622 & 0.328 \\
\hline Var6e & 0.505 & 0.573 \\
\hline Var6f & 0.186 & 0.684 \\
\hline Var6g & 0.125 & 0.827 \\
\hline Var6h & 0.309 & 0.707 \\
\hline Var6i & 0.692 & 0.307 \\
\hline Explained variance & 2.954 & 2.378 \\
\hline Share & 0.328 & 0.264 \\
\hline
\end{tabular}

By analysing the above results, it may be noted that the first main factor (F1) explains $47.86 \%$ of the total variance. These factors include: lower energy bills for consumers (Var6a); larger awareness of consumers in the area of the potential of energy efficiency (Var6b); better relations between energy suppliers, distributors and clients (Var6c); lower costs of producing (and supplying) energy for the media (Var6d), a better business and administrative environment for future innovative energy services (Var6e) and increased competitiveness on energy markets (Var6i). These variables can be considered as an area of building mutual relations on the energy market. The second main factor (F2), which describes $11.37 \%$ of the total variance, covers the following variables: aggregation of small investments (combining into packages/packaging) (Var6f); preparation of new financing models, e.g., contracting the energy characteristics (Var6g) and stimulation of energy-efficient renovation of buildings (Var6h). These variables can be considered as an area for increasing the efficiency of the energy market. Measurements obtained as a result of the factor analysis indicate the differences in perceiving the potential benefits from the application of the directive on energy efficiency. Average values of scores were defined for the distinguished factors. An average score of the first factor, F1, amounts to 1.55, whereas for factor two, F2, it is 1.8. This means that factors relating to building market relations in terms of benefits are assessed as less relevant than those relating to measures to increase the energy market efficiency. At the same time, the scores indicate that both aspects are important upon deciding on proceeding in accordance with the concept of energy efficiency in enterprises. The value of both factors, used in further analysis, were estimated using the regression method, which takes account of the factor loads of the individual variables within the given factor. 
3.3. Assessment of the Influence of Directive 2012/27/EU on Energy Management in EU Enterprises, Using a Logistic Regression

The purpose of further research is to answer the following exploratory questions:

1. How does the logarithmic probability of energy management in an enterprise change due to the approach to the EU guidelines on energy-saving products and services?

2. What is the probability that an organization will execute implementation of energy efficiency in its operations, in good legal and marketing conditions?

The logistic regression model is a special case of the general line model. This model is based on the logistic function and it can be represented by the following formula [35]:

$$
f(z)=\frac{e^{2}}{1+e^{2}}
$$

This model is applicable when the dependent variable is dychotomic; in a mathematical formula, these values are represented by numbers 1 and 0 . In order to determine whether the energy management declaration in an enterprise results from the understanding of the Directive and its benefits, the answer to the question about energy management in companies' operations has been identified as a dependent variable. A positive "yes" answer has been coded as 1 and a negative "no" as 0 . The coding for all the variables to be assigned to the model is shown in Table 7.

Table 7. Input variables for the logistic regression model.

\begin{tabular}{|c|c|c|}
\hline Variables & Code & Designation \\
\hline \multicolumn{3}{|c|}{ Dependent variable } \\
\hline Energy management in an enterprise & $\begin{array}{l}0 \text { - no energy management } \\
1 \text { - energy management }\end{array}$ & Var1 \\
\hline \multicolumn{3}{|c|}{ Independent variables-predictor } \\
\hline $\begin{array}{l}\text { Clarity of guidelines in regard to the implementation of } \\
\text { energy-saving products and services in the given country }\end{array}$ & $\begin{array}{l}0 \text {-no } \\
1 \text {-yes }\end{array}$ & Var2 \\
\hline $\begin{array}{l}\text { Visibility of information campaigns or other public initiatives } \\
\text { concerning energy-saving products and services }\end{array}$ & $\begin{array}{l}0 \text {-no } \\
1-\text { yes }\end{array}$ & Var3 \\
\hline Clarity of laws on energy measurement and settlements & $\begin{array}{l}0 \text {-no } \\
1-\text { yes }\end{array}$ & Var4 \\
\hline Clarity of definitions of energy-saving products and services & $\begin{array}{l}0-\text { no } \\
1-\text { yes }\end{array}$ & Var5 \\
\hline \multicolumn{3}{|c|}{ Assessment of potential benefits of the current energy efficiency system } \\
\hline Factor 1 & 0 -I do not agree & F1 \\
\hline Factor 2 & 1-I agree & F2 \\
\hline
\end{tabular}

Independent variables, defined as predictors, are to indicate the probability of the foreseen execution of guidelines on energy efficiency amongst entities. The built logistic regression model allows examining the influence of the identified independent variables on one dependent variable.

To adjust the variables to the model, first, the Hosmer-Lemeshow test was conducted, which compares, for various subgroups, the observed number of independent variable values and the foreseen probability of occurrence of an energy management event in EU enterprises. If these variables are sufficiently close, then it can be assumed that a well-adjusted model has been built.

It is assumed that:

H0: Var1 = Var2, Var3, Var4, Var5, F1, F2 for all categories

H1: Var1 $\neq$ Var2, Var3, Var4, Var5, F1, F2 for at least one category. 
The procedure of estimating the good fit of the model was based on the chi-square test. The calculation algorithm assumed a division of the observation from the sample into subgroups, differentiated by the probability of achieving the criterion value of the dependent variable (i.e., equal to 1). The number of freedom degrees for these statistics was 8 . The Hosmer and Lemeshow good fit test compares values expected on the basis of the model with values observed, where a lack of significance of the chi-square coefficient means that the division of probability foreseen on the basis of the model is not substantially different than that of observed results of the sample [36]. The result of the Hosmer and Lemeshow test is statistically insignificant (chi-square $=13.83 ; p=0.086$ ), meaning that the data is well adjusted to the model. The model of forecasting on the basis of estimated coefficients is substantially similar.

The chi-square test concerning the level of significance of the model allow verifying the hypothesis that the predictors in the model explain the probability of occurrence of an energy management event. The significance of predictors at the level of $p<0.05$ means that they explain the substantial probability that EU enterprises, affected by these predictors, deal with energy issues in their management strategy. To check the degree, to which the variance of independent variables explains the variance in the occurrence of the event, the value of determinant coefficients was calculated (Table 8). R2 Cox and Snell statistics amounted to 0.49. Since this test never reaches the theoretical maximum equal to 1 , a modification of this coefficient is calculated in the form suggested by R2 Nagelkerk. The R-square Nagelkerk coefficient of $R^{2}=0.709$ indicates that the variance model for sex and age explains approximately $71 \%$ of the variance in the probability of the occurrence of energy management in entities.

Table 8. Model—summary.

\begin{tabular}{ccc}
\hline -2 Reliability Logarithm & R-Square by Cox and Snell & R-Square by Nagelkerk \\
\hline 10.987 & 0.490 & 0.709 \\
\hline
\end{tabular}

The estimation of the value of the regression model parameters are presented in Table 9. The significance or predictors was estimated on the basis of the Wald test and it determines which independent variables significantly decrease or increase the probability of occurrence of energy management in EU enterprises. This may be presented as follows:

H0: Lack of the predictor's influence on the dependent variable;

H1: The predictor's influence on the dependent variable.

Table 9. Estimation of the value of parameters of the logistic regression model.

\begin{tabular}{ccccccc}
\hline Variables & $\mathbf{B}$ & Standard Error & Wald & $\mathbf{d f}$ & Significance & Exp(B) \\
\hline Var2 & $\mathbf{1 . 3 3}$ & $\mathbf{0 . 1 3}$ & $\mathbf{0 . 0 0 0}$ & $\mathbf{1}$ & $\mathbf{0 . 0 1 2}$ & 0.020 \\
\hline Var3 & $\mathbf{6 . 2 8}$ & $\mathbf{4 . 8 4}$ & $\mathbf{1 . 6 8 3}$ & $\mathbf{1}$ & $\mathbf{0 . 0 2 4}$ & 0.002 \\
\hline Var4 & 0.64 & 3.07 & 0.043 & 1 & 0.836 & 1.891 \\
\hline Var5 & $\mathbf{1 . 0 5}$ & $\mathbf{0 . 2 2}$ & $\mathbf{0 . 0 0 0}$ & $\mathbf{1}$ & $\mathbf{0 . 0 0 9}$ & 8.947 \\
\hline F1 & -0.85 & 1.62 & 0.278 & 1 & 0.598 & 0.427 \\
\hline F2 & 0.83 & 1.52 & 0.300 & 1 & 0.584 & 2.296 \\
\hline Constant & 2.72 & 2.19 & 1.538 & 1 & 0.215 & 15.200 \\
\hline
\end{tabular}

Among all independent variables, only three of them significantly affect the examined phenomenon of energy management in EU enterprises. It has been demonstrated that the clarity of guidelines in regard to the implementation of energy-saving products and services in the given country (Var2), as well as the clarity of definitions of energy-saving products and services set forth in directive 2012-27-EU (Var5), influences effective energy management. These factors positively affect the probability of effective energy management in examined entities. This means that a lack of clear and transparent 
instructions concerning the performance of energy-saving activities and a lack of a detailed definition of energy-saving products and services result in the EU enterprises' willingness to deal with energy management in their operations in an effective manner and in accordance with EU guidelines. The probability of effective energy management in examined entities grows along with the availability of advertising campaigns, which promote the concept of energy-saving products and services (Var3).

EU enterprises, which understand the guidelines and definitions of energy-saving products and services are more willing to perform activities contributing the effective energy management. Improper understanding of the formal rules related with the implementation of the directive means that examined entities are reluctant to or wrongly interpret the provisions. This allows to positively verify the third research hypothesis (H3), a lack of understanding of the content of the directive increases the probability of reluctance to manage energy in the examined entities. Within the meaning of the directive, one of the barriers may be the specialist and difficult language of the directive.

\section{Conclusions}

According to Skare et al. [37], the increased total consumption of energy hinders sustainable growth and the execution of the green economy concept. This is particularly affected by the increased consumption of energy in the industrial sector, which is most harmful for the environment and may be partially neutralized by using renewable and alternative energy sources. Studies prepared by the authors suggest that drawing up an environmental strategy regulating the consumption of fossil fuel may be beneficial for the economic growth of European countries. A similar standpoint is presented by Šimkova et al. [38]; in their opinion, seeking solutions for the problem of obtaining energy from national energy resources should be exercised in accordance with the concept of sustainable growth. Joint attempts to effectively manage energy at the EU level obligates the principal managing authorities to create conditions that allow implementing this concept at the level of individual enterprises. The essence of such procedure is underlined by Bołoz and Midor [39], according to whom to be competitive, a contemporary enterprise must meet certain ethical standards addressing, amongst others, rational use of available energy sources. The authors demonstrate that caring for sustainable growth, including energy efficiency, is important for enterprises also from the point of view of their social image. Herbus and Ślusarczyk [40] additionally mention the aspect of corporate social responsibility, which covers not only the enterprises that use the energy but also energy producers. Accordingly, social criteria have significant influence on business decisions of energy companies, which is dictated by the growing awareness of the influence of business activity on the environment. Strielkowski [41] notes the aspect of using renewable solar energy, which could bring benefits in the area of controlling environmental threats caused by the use of nonrenewable energy in the environment.

In turn, the results of research by Kasperowicz and Štreimikiene [42] demonstrate that economic growth of European countries depends on the type and level of used energy sources. What's more, they claim that improper use of energy constitutes a factor that limits economic growth. This is an important argument in favour of observing the basic rules of effective energy management by the important group of consumers-the enterprises. This is particularly true in consideration of the use of energy as a cause of contamination, including $\mathrm{CO}_{2}$ emissions [43,44]. Based on the example of Czech Republic enterprises, Smékalová et al. [45] demonstrate that support for entrepreneurship from government institutions, other than financial, is low. Enterprises need support especially in terms of adaptation to new environmental conditions, and also social acceptance of their activities, which requires greater involvement of public institutions in implemented marketing campaigns. This is confirmed by our study results, according to which enterprises have limited support in the scope of effective energy management as defined by directive 2012-27-EU. This hinders adjusting to the applicable formal requirements and limits organizational and technological possibilities resulting from the recommended changes in operations. Some of these problems are better explained in Directive 2018/2002 of the European Parliament and of the Council of 11 December 2018 amending Directive 2012/27/EU on energy efficiency [46]. 
In consideration of the variability of power systems, Lisin et al. [47] propose in their studies to take account of the differences in the functioning of these systems, and, on this basis, to select the best solution to reduce the energy intensity. Clearly planned and organized activities at the level of national authorities, addressed to various groups of recipients, including entrepreneurs, may positively affect the energy efficiency of the entire country. Szkutnik and Jakubiak propose to apply intelligent energy meters within the scope of the "SMARTEFEKT" project, which consists of the following modules: "communication, settlement \& analytical and information \& discussion" [48] (p. 122), [49].

Achieving the desirable energy efficiency constitutes a serious challenge for many European Union countries, where reported energy savings are usually smaller than obligatory values. In case of business activity, energy constitutes the basic resource in the processes of production and satisfying market needs, therefore, achieving higher performance seems difficult and complicated. The conducted studies demonstrated that one of the reasons of the failure to adjust to EU regulations was the lack of clarity of applicable laws. The way in which EU enterprises perceive the provisions of the directive demonstrates that the document does not fully resolve the existing dilemmas for these market participants, mainly private enterprises [19].

Obtained results indicated certain barriers, which may restrict the adjustment of enterprises to the requirements related with increasing energy efficiency in their operations. First, the entities are mostly lacking a specific set of solutions to allow effective implementation of the directive; second, a large group of entrepreneurs does not understand and has no knowledge on how to properly manage energy. Entities are not sufficiently engaged in the execution of the energy efficiency concept pursuant to EU guidelines. At the same time, the clarity and transparency of related regulations is rated low. Enterprises are sceptical about the possible benefits of observing regulations. At the same time, it was demonstrated that a lack of understanding of the content of the directive results in reluctance to manage energy. Enterprises require more accessible and understandable programs, meetings and campaigns promoting the adjustment to the applicable regulations on effective use of energy. A lack of knowledge and awareness in surveyed organizations hinders the optimum use of energy in business activity. These are the reasons of improper energy management in entities, which confirm that unclear and simplified provisions of the directive reduce the engagement of businesses in activities contributing to increasing energy efficiency in their operations. A lack of knowledge and awareness of surveyed organizations hinders the optimum use of energy in business operations. Such regulations require updates and uniformity in the scope of definitions and tools to achieve the desired energy performance in companies.

Previous research was directed at a general analysis and influence of the use of energy, regardless of the group of recipients, and presented a limited point of view on the discussed issue. Our study may serve as an indicator to understand successful implementation of regulations and provisions on effective energy management in both enterprises and other energy consumer groups. Future research should also include studies of other entities being participants of the energy system, because it may be assumed that the lack of clarity of regulations and the lack of relevant solutions constitute the main source of excessive use of nonrenewable and harmful energy sources in various EU countries.

The results of this research have important implications for government decision-makers, energy suppliers and enterprises. In preparing regulations and recommendations on energy efficiency, legislative bodies should take account of the readiness and conditions of entities. It should be decided how to support enterprises in understanding and effective implementation of EU laws, which cover not only energy management but also environmental protection. Finally, the conducted research should help companies to start their own ecological initiatives. Enterprises need more accessible and understandable documents, meetings and campaigns promoting the adjustment to applicable laws on effective energy use. The results of the study also confirm the most important problems and challenges in the area of adjusting to the new regulations. Providing expert knowledge and tools addressed to enterprises constitutes the basic challenge of EU authorities, in order to ensure the expected energy efficiency in the community. 
Author Contributions: Conceptualization, K.G.; methodology, K.G.; validation, software A.A.; Z.D.-P.; formal analysis, A.A.; investigation, K.G.; resources, Z.D.-P.; data curation, A.A.; writing-original draft preparation, K.G.; writing-review and editing, K.G.; visualization, Z.D.-P.; supervision Z.D.-P.; project administration, A.A.; funding acquisition, Z.D.-P. All authors have read and agreed to the published version of the manuscript.

Funding: This research received no external funding.

Conflicts of Interest: The authors declare no conflict of interest.

\section{References}

1. Cruz-Lovera, C.; Perea-Moreno, A.; Cruz-Fernández, J.; Alvarez-Bermejo, J.; Manzano-Agugliaro, F. Worldwide research on energy efficiency and sustainability in public buildings. Sustainability 2017, 9, 1294. [CrossRef]

2. Ganda, F.; Ngwakwe, C.C. Role of energy efficiency on sustainable development. Environ. Econ. 2014, 5, 86-99.

3. Kucęba, R.; Pabian, A.; Bylok, F. Energy security intensification determinants in the chains of final Energy vale creation. Pol. J. Manag. Stud. 2010, 2, 68-80.

4. Zhao, L.; Zhou, Z. Developing a Rating System for Building Energy Efficiency Based on in Situ Measurement in China. Sustainability 2017, 9, 208. [CrossRef]

5. Zangheri, P.; Economidou, M.; Labanca, N. Progress in the implementation of the EU Energy Efficiency Directive through the lens of the national annual reports. Energies 2019, 12, 1107. [CrossRef]

6. Rosenow, J.; Bayer, E. Costs and benefits of Energy Efficiency Obligations: A review of European programmes. Energy Policy 2017, 107, 53-62. [CrossRef]

7. Nabitz, L.; Hirzel, S. Transposing the requirements of the energy efficiency directive on mandatory energy audits for large companies: A policy-cycle-based review of the national implementation in the EU-28 member states. Energy Policy 2019, 125, 548-561. [CrossRef]

8. Hsueh, S.; Yan, M. Enhancing sustainable community developments: A multi-criteria evaluation model for energy efficient project selection. Energy Procedia 2011, 5, 135-144. [CrossRef]

9. Eichhammer, W.; Worrell, E.; Fleiter, T. Barriers to energy efficiency in industrial bottom-up energy demand models-A review. Renew. Sustain. Energy Rev. 2011, 15, 3099-3111. [CrossRef]

10. Backlund, S.; Thollander, P.; Palm, J.; Ottosson, M. Extending the energy efficiency gap. Energy Policy 2012, 51, 392-396. [CrossRef]

11. Olsen, K.H.; Fenhann, J. Sustainable development benefits of clean development mechanism projects: A new methodology for sustainability assessment based on text analysis of the project design documents submitted for validation. Energy Policy 2008, 36, 2819-2830. [CrossRef]

12. Dahmus, J.B. Can efficiency improvements reduce resource consumption? A historical analysis of ten activities. J. Ind. Ecol. 2014, 18, 883-897. [CrossRef]

13. Galvin, R. Estimating broad-brush rebound effects for household energy consumption in the EU 28 countries and Norway: Some policy implications of Odyssee data. Energy Policy 2014, 73, 323-332. [CrossRef]

14. Vassileva, I.; Campillo, J. Increasing energy efficiency in low-income households through targeting awareness and behavioral change. Renew. Energy 2014, 67, 59-63. [CrossRef]

15. Aparisi, T.D.; Ekins, P. Energy efficiency and resource efficiency: A key relationship, Exploring the Links Between Energy Efficiency and Resource Efficiency. Sci. Environ. Policy 2015, 49. [CrossRef]

16. Abhyankar, N.; Phadke, A. Impact of large-scale energy efficiency programs on utility finances and consumer tariffs in India. Energy Policy 2012, 43, 308-326. [CrossRef]

17. Available online: https://ec.europa.eu/energy/sites/ener/files/documents/2012_energy_roadmap_2050_en_0. pdf (accessed on 18 August 2020).

18. EU Climate Action. Available online: https://ec.europa.eu/clima/policies/strategies/2030_pl (accessed on 10 April 2020).

19. Directive 2012/27/EU of the European Parliament and of the Council. Available online: https://eur-lex.europa. eu/legal-content/EN/TXT/?uri=celex\%3A32012L0027 (accessed on 10 April 2020).

20. OECD. OECD Contribution to the United Nations Commission on Sustainable Development 15 Energy for Sustainable Development; OECD Publications: Paris, France, 2007. 
21. Available online: https://www.europarl.europa.eu/RegData/etudes/BRIE/2015/568361/EPRS_BRI\%282015\% 29568361_EN.pdf (accessed on 18 August 2020).

22. Commission Staff Working Document, Accompanying the Document, Report Form the Commision to the European Parliament and the Council, Assessment of the Progress Made by Member States towards the National Energy Efficiency Targets for 2020 and towards the Implementation of the Energy Efficiency Directive 2012/27/EU as Required by Article 24 (3) of Energy Efficiency Directive 2012/27/EU, European Commision, Brussels 2015. Available online: https:/eur-lex.europa.eu/legal-content/EN/TXT/?uri=CELEX\% 3A52015SC0245 (accessed on 18 August 2020).

23. Marszal, A.J.; Heiselberg, P.; Bourrelle, J.S.; Musall, E.; Voss, K.; Sartori, I.; Napolitano, A. Zero energy building-A review of definitions and calculation methodologies. Energy Build 2011, 43, 971-979. [CrossRef]

24. European Commission. A 2016 Assessment of the Progress of Member States in 2014 in the Area of Achieving the 2020 National Values of Energy Efficiency, and in the Implementation of Directive 2012/27/EU on Energy Efficiency, Conducted in Accordance with Article 24.3 of Directive 2012/27/EU on Energy Efficiency; Commission Report for the European Parliament; European Commission: Brussels, Belgium, 2012.

25. Haseeb, M.; Kot, S.; Iqbal-Hussai, H.; Jermsittiparsert, K. Impact of economic growth, environmental pollution, and energy consumption on health expenditure and R\&D expenditure of ASEAN countries. Energies 2019, 12, 3598. [CrossRef]

26. Consultation_on_the_Review_of_Directive_2012-27-EU_on_Energy_Efficiency. Available online: https: //ec.europa.eu/energy/en/consultations/consultation-review-directive-201227eu-energy-efficiency (accessed on 18 August 2020).

27. Trochim, W. Changes and Additions, Conjoint.ly. 2020. Available online: https://conjointly.com/kb/\#what-isthe-research-methods-knowledge-base (accessed on 12 May 2020).

28. Kowal, J. Metody opisu statystycznego w zarządzaniu. In Zarzadzanie Przedsiębiorcze, 1st ed.; Knecht, Z., Ed.; WSZ E: Wrocław, Poland, 2011; pp. 107-114.

29. Pełka, M. Regresja logistyczna dla danych symbolicznych interwałowych. Econometrics 2015, 2, 44-45. [CrossRef]

30. Fang, J. Why logistic regression analyses are more reliable than multiple regression analyses. J. Bus. Econ. 2013, 4, 623-625.

31. Borucka, A.; Grzelak, M. Application of logistic regression for production machinery efficiency evaluation. Appl. Sci. 2019, 9, 4770. [CrossRef]

32. Kowalska-Musiał, M. Analiza czynnikowa w badaniach struktury relacji w marketingu relacyjnym. In Przedsiębiorstwo i Klient w Gospodarce Opartej na Ustugach; Rudowska, I., Soboń, M., Eds.; Difin: Warsaw, Poland, 2009; pp. 2-3.

33. Rodríguez-Santero, J.; Torres-Gordillo, J.; Gil-Flores, J. Confirmatory factor analysis of a questionnaire for evaluating online training in the workplace. Sustainability 2020, 12, 4629. [CrossRef]

34. Cheba, K. Wykorzystanie analizy czynnikowej do wielowymiarowej oceny możliwości rozwoju prośrodowiskowej orientacji przedsiębiorstw. Śląski Przegląd Stat. 2013, 11, 275-288.

35. Hosmer, D.W.; Lemeshow, S. Applied Logistic Regression, 2nd ed.; Wiley \& Sons: New York, NY, USA, 2000.

36. Danieluk, B. Zastosowanie regresji logistycznej w badaniach eksperymentalnych. Psychol. Społeczna 2010, 2, 199-216.

37. Skare, M.; Tomic, D.; Stjepanovic, S. Energy consumption and green GDP in Europe: A panel cointegration analysis 2008-2016. Acta Montan. Slovaca 2020, 25, 1. [CrossRef]

38. Šimkova, Z.; Očenášová, M.; Tudoš, D.; Rót, B. The political frame of the European Union for mining of non-energetic raw materials. Acta Montan. Slovaca 2019, 24, 35-43.

39. Bołoz, Ł.; Midor, K. The procedure of choosing an optimal offer for a conical pick as an element of realizing the sustainable development concept in mining enterprises. Acta Montan. Slovaca 2019, 24, 140-150.

40. Herbuś, A.; Ślusarczyk, B. The use of corporate social responsibility idea in business management. Pol. J. Manag. Stud. 2012, 6, 234-240.

41. Strielkowski, W. Entrepreneurship, sustainability, and solar distributed generation. Int. J. Entrep. Sustain. 2016, 4. [CrossRef]

42. Kasperowicz, R.; Štreimikienè, D. Economic growth and energy consumption: Comparative analysis of V4 and the "old" EU countries. J. Int. Stud. 2016, 9, 181-194. [CrossRef] 
43. Kasperowicz, R. Economic growth and $\mathrm{CO}_{2}$ emissions: The ECM analysis. J. Int. Stud. 2015, 8, 91-98. [CrossRef]

44. Mesagan, E.P.; Chidi, O.N. Energy consumption, capital investment and environmental degradation: The african experience. Forum Sci. Oeconomia 2020, 8. [CrossRef]

45. Smékalová, L.; Hájek, O.; Belás, J.; Macháček, J. Perception of small and medium entrepreneurship in the Czech Republic. J. Compet. 2014, 6, 41-49. [CrossRef]

46. Dyrektywa Parlamentu Europejskiego zmieniająca dyrektywę 2012/27/UE w sprawie efektywności energetycznej. Dyrektywa Parlamnetu Europejskiego i Rady (UE) 2018/2002 z dnia 11 grudnia 2018 r; European Commision, Brussels. 2018. Available online: https://eur-lex.europa.eu/legal-content/PL/TXT/PDF/?uri= CELEX:32018L2002\&from=EN (accessed on 18 August 2020).

47. Lisin, E.; Kurdiukova, G.; Ketoeva, N.; Katina, J. Sustainability issues of territorial power systems in market conditions. Int. J. Entrep. Sustain. 2018, 6, 1041-1052. [CrossRef]

48. Szkutnik, J.; Jakubiak, D. New trends in consumptions management of electric energy. Pol. J. Manag. Stud. 2012, 5, 120-127.

49. Androniceanu, A.; Popescu, C.R. An inclusive model for an effective development of the renewable energies public sector. Adm. Manag. Public 2017, 28, 81-96.

(C) 2020 by the authors. Licensee MDPI, Basel, Switzerland. This article is an open access article distributed under the terms and conditions of the Creative Commons Attribution (CC BY) license (http://creativecommons.org/licenses/by/4.0/). 